\title{
Manajemen Laba dan Faktor yang Mempengaruhinya
}

\author{
Devi Permatasari \\ Rosa Tiana Aprilia Wulandari \\ Program Studi Akuntansi, Fakultas Ekonomi \\ Universitas Islam Sultan Agung \\ Email:devi p@unissula.ac.id
}

\begin{abstract}
ABSTRAK
Penelitian ini menginvestigasi faktor-faktor yang berpengaruh pada manajemen laba. Dimana faktor tersebut antara lain beban pajak tangguhan, kecakapan manajerial, serta perencanaan pajak. Penelitian ini menggunakan perusahaan manufaktur yang listing di BEI periode 2016-2018 sebagai populasi. Selanjutnya, sampel diambil menggunakan teknik purposive sampling, dimana total sampel yang didapat sebanyak 150 perusahaan manufaktur. Teknik analisis menggunakan metode regresi linier berganda yang dibantu dengan alat analisis SPSS 22. Penelitian ini memberikan hasil bahwa beban pajak tangguhan memiliki pengaruh positif terhadap manajemen laba. Sedangkan perencanaan pajak serta kecakapan manajerial tidak berpengaruh pada manajemen laba.
\end{abstract}

Kata kunci : beban pajak tangguhan, perencanaan pajak, kecakapan manajerial, manajemen laba.

\begin{abstract}
This study investigates the factors that influence earnings management. Where these factors include deferred tax expense, managerial skills, and tax planning. This study uses manufacturing companies listed on the IDX for the 2016-2018 period as a population. Furthermore, the sample was taken using purposive sampling technique, where the total sample obtained was 150 manufacturing companies. The analysis technique uses multiple linear regression methods assisted by SPSS 22 analysis tools. This study provides the result that deferred tax expense has a positive effect on earnings management. Meanwhile, tax planning and managerial skills have no effect on earnings management.
\end{abstract}

Keywords: deferred tax expense, tax planning, managerial skills, earnings management.

\section{PENDAHULUAN}

Penilaian kinerja di dalam perusahaan dapat tercermin tingkat laba yang tercapai di dalam perusahaan. Perusahaan memiliki pihak yang berkepentingan yang dapat menggunakan informasi laba tersebut dalam menentukan sebuah keputusan untuk kelangsungan operasional perusahaan tersebut. Informasi laba di dalam suatu perusahaan dapat dipakai oleh pihak internal dan eksternal perusahaan sebagai dasar dalam pengambilan sebuah keputusan. Oleh karena itu kualitas dari laba yang disajikan perusahaan tentunya sangat menarik perhatian dari berbagai kalangan baik investor, kreditor dan para pembuat kebijakan akuntansi, 
maupun pemerintah, yaitu Direktorat Jendral Pajak.

Dalam mengelola sebuah perusahaan, pihak manajemen secara langsung tentu dapat memperoleh laba yang sangat tinggi, hal ini tentu berpengaruh langsung pada bonus yang dapat diperoleh dari pihak manajemen atas kinerja yang telah dilakukan. Perusahaan kini menghadapi berbagai macam persaingan yang ketat untuk dapat bertahan dalam pasar global, tentunya industri manufaktur di Indonesia yang tidak luput dari kerasnya arus persaingan. Perusahaan dituntut untuk memiliki keunggulan kompetitif agar bisa dan mampu untuk bersaing dengan perusahaan lainnya, tidak hanya dari kuantitas maupun kualitas, namun juga mencakup berbagai pengelolaan keuangan dengan baik. Dalam artian, pelaksanaan pengelolaan keuangan yang baik akan mendukung keberlangsungan usaha, dan akan diperlihatkan dengan pencapaian laba perusahaan. Kondisi tersebut mampu mendorong manajer untuk melakukan earnings management dalam hal penyajian dan pelaporan informasi laba (Aditama dan Purwaningsih, 2014).

Manajemen laba merupakan suatu tindakan yang dilaksanakan dari pilihan beberapa kebijakan akuntansi yang ada di perusahaan untuk mencapai tujuan tertentu. Manajemen laba bisa terjadi karena laporan keuangan disusun berdasarkan basis akrual. Manajemen laba bisa terjadi saat manajer memakai penilaian pada pelaporan keuangan, sehingga menyesatkan penilaian bagi stakeholder tentang kinerja suatu perusahaan (Healy dan Wahlen et al., 1999). Dilakukannya manajemen laba yang ada di dalam laporan keuangan dengan mempermainkan komponen yang akrual, dikatakan akrual karena sesuai dengan harapan orang-orang yang melakukan transaksi di dalam menyusun laporan keuangan (Sulistyanto, 2008). Perusahaan melakukan manajemen laba agar sebuah laporan keuangan di dalam perusahaan terlihat lebih baik. Karena investor yang memiliki kecenderungan untuk melihat sebuah laporan keuangan di dalam menilai atau mengukur suatu perusahaan.

Manajemen laba dianggap telah menjadi suatu kebiasaan yang terjadi dalam perusahaan. Hal ini bisa dilihat dari kasus yang terjadi di PT Toshiba, dimana terjadi tindakan penggelembungan laba karena adanya kerugian yang terjadi di perusahaan tersebut. PT Toshiba tidak mampu mencapai target laba yang diharapkan. Tindakan manajemen laba di PT Toshiba ini terjadi selama beberapa tahun yang dilakukan oleh CEO, dan efek yang terjadi akibat tindakan ini mengakibatkan dihapusnya saham PT Toshiba dan penjualan juga mengalami penurunan.

Pajak memiliki aspek dan peran yang sangat penting dalam proses pembangunan khususnya di Indonesia. Penerimaan Negara terbesar yaitu peranan sektor perpajakan dalam mendukung penerimaan Negara. Kondisi perekonomian dapat menciptakan persaingan yang mampu mengelola keuangan dengan baik untuk menghasilkan suatu laba. Manajer perusahaan wajib melakukan pembayaran pajak, sehingga diperlukan suatu perencanaan yang baik. Perencanaan pajak merupakan langkah pertama di dalam pelaksanaan manajemen pajak. Tujuannya adalah beban pajak (tax expense) direkayasa untuk serendah mungkin ditekan sesuai dengan peraturan yang ada, sehingga perencanaan pajak hampir sama dengan tax avoidance yang pada hakikatnya sama-sama penghasilan dimaksimalkan setelah pajak karena merupakan pengurangan laba. Pentingnya informasi laba mendorong manajer melakukan intervensi di dalam proses laporan keuangan untuk mencapai suatu tujuan tertentu. Apabila peerusahaan memiliki kualitas yang baik, maka investor juga tertarik untuk 
menjadi pemilik saham tersebut. Manajemen perusahaan menginginkan suatu laba yang diminimalkan suatu laba kena pajak yang dilaporkan untuk keperluan pajak (Ettredge et al,. 2008).

Perencanaan pajak (Tax Planning) merupakan langkah pertama di dalam pelaksanaan manajemen pajak. Dilakukannya pengumpulan serta penelitian terhadap peraturan perpajakan agar dapat dilakukan seleksi melalui penghematan yang akan dilakukan (Achyani dan Lestari, 2019). Dengan melakukan suatu perencanaan pajak yang tepat dan legal, perusahaan mendapatkan laba bersih yang rasional dan lebih besar dibandingkan perusahaan yang tidak melakukan perencanaan pajak (Romantis et al, 2020). Perencanaan pajak merupakan upaya untuk menekankan beban pajak penghasilan perusahaan. Dengan adanya perencanaan pajak yang efektif maka akan memberikan efisiensi bagi beban pajak perusahaan sehingga dapat meningkatkan ekuitas yang ada di dalam perusahaan.

Wijaya dan Martani (2011) menyarankan beberapa alternatif yang dapat digunakan untuk mengolah variabel yang terkait dengan perencanaan pajak dengan melalui berbagai aspek yaitu proyeksi pajak, bentuk usaha, bidang usaha, pengawasan atau pemeriksaan pajak, kebijakan akuntansi yang dapat berpengaruh dalam menggapai penurunan tarif pajak sesuai UU No 36 tahun 2008.

Terdapat berbagai hasil penelitian sebelumnya mengenai hubungan perencanaan pajak dan manajemen laba. Wijaya dan Martani (2011), Sumomba dan Hutomo (2012), Aditama dan Purwaningsih (2014) dan Prasetyo et. al (2019) menyatakan bahwa perencanaan pajak memiliki pengaruh positif terhadap terjadinya tindakan manajemen laba di perusahaan. Sedangkan, penelitian dari Romantis er al. (2020), menunjukkan hal sebaliknya, bahwa perencanaan pajak yang kecil membuat tindakan manajemen laba menjadi tinggi. Selanjutnya, Sylvia (2016) dan Achyani dan Lestari (2019) memberikan hasil yang berbeda, yaitu tidak terdapat pengaruh antara perencanaan pajak yang dilakukan dengan tindakan manajemen laba di perusahaan.

Menurut Phillips, et al., (2003) beban pajak tangguhan merupakan beban yang muncul karena adanya perbedaan temporer yang terjadi antara laba akuntansi dan laba fiskal. Perbedaan dari laporan keuangan akuntansi dan laporan keuangan fiskal disebabkan oleh penyusunan laporan keuangan, pihak manajemen diberikan keleluasaan dalam menentukan prinsip akuntansi dibandingkan dengan penyusunan laporan keuangan menurut peraturan perpajakan. Penelitian Wiryandari et al., (2009) menguji manajemen laba yang dideteksi dengan beban pajak tangguhan, yaitu laba bersih dibagi dengan nilai ekuitas awal tahun dengan menunjukan ekspektasi pasar dalam laba yang dilaporkan. Beban pajak tangguhan memiliki hubungan positif dengan manajemen laba untuk menghindari kerugian yang ada di dalam perusahaan. Karena itu perbedaan antara laba akuntansi yang ada di dalam perusahaan dan penghasilan kena pajak akan merefleksikan tingkat kebijakan dari manajer di dalam mengelola laba menjadi lebih tinggi (Lestari, 2018). Beban pajak tangguhan akan naik seiring dengan meningkatnya suatu kewajiban pajak tangguhan bersih. Kewajiban tangguhan bersih dapat diperoleh dari selisih yang terjadi antara kewajiban pajak tangguhan dengan aktiva pajak tangguhan (Djamaluddin, dkk, 2008).

Penelitian sebelumnya mengenai beban pajak tangguhan dan manajemen laba juga memberikan hasil yang berbeda-beda. Hasil positif signifikan antara pengaruh beban pajak tangguhan dan manajemen laba dilakukan oleh Yulianti (2005), Ulfah (2013) Lestari (2018) dan Widowati et al. (2019). Sedangkan penelitian 
yang dilakukan Sylvia (2016), Achyani dan Lestari (2019), dan Prasetyo et al. (2019) menyatakan tidak ada pengaruh antara beban pajak tangguhan dan tindakan manajemen laba.

Kecakapan manajerial yaitu suatu keterampilan personal yang dapat membantu suatu kinerja yang tinggi dalam tugas manajemen dapat tercapai (Puspita dan Kusumaningtyas, 2017). Manajer yang memiliki tingkat kecakapan manajerial yang tinggi akan lebih terampil di dalam mengolah suatu informasi, sehingga mampu melakukan intervensi dalam proses pelaporan keuangan agar tidak menimbulkan manipulasi laba. Demerijan, dkk (2006) menguji pengaruh kecakapan manajerial terhadap manajemen laba. Dimana, seorang manajer yang semakin cakap membuat laba yang diperoleh perusahaan juga semakin berkualitas (Wicaksono dan Yuyetta, 2013). Kecakapan manajerial yang dimaksud adalah kecakapan manajerial di dalam bidang keuangan, yaitu seberapa efisien perusahaan di dalam bidang keuangan secara relatif terhadap perusahaan lain di dalam industri yang sama (Utami dan Syafruddin, 2013).

Utami dan Syafruddin (2013) serta Wicaksono dan Yuyetta (2013) memberikan hasil penelitian bahwa manajer yang cakap berpengaruh pada terjadinya tindakan manajemen laba di perusahaan. Berbanding terbalik dengan penelitian yang dilakukan oleh Septiana (2012), bahwa tidak ada pengaruh antara kecakapan yang dimiliki oleh manajer dengan tinggi atau rendahnya tindakan manajemen laba.

Penelitian ini dilakukan untuk mengetahui penyebab terjadinya manajemen laba di perusahaan manufaktur. Dimana praktek manajemen laba ini masih sering dilakukan di dalam perusahaan untuk memberikan kesan laba yang baik. Praktik manajemen laba dalam penelitian ini bisa dideteksi dengan melihat adanya perencanaan pajak yang dilakukan perusahaan. Adanya beban pajak tangguhan juga bisa menjadi salah satu pendeteksi terjadinya tindakan manajemen laba. Selanjutnya, manajemen laba juga bisa terjadi bila perusahaan memiliki manajer yang cakap dan mumpuni. Selain itu, terdapat beberapa perbedaan hasil penelitian sebelumnya yang membuat penelitian mengenai manajemen laba masih sangat menarik untuk diteliti.

\section{LANDASAN TEORI DAN PENGAMBANGAN HIPOTESIS}

\section{Perencanaan Pajak (Tax Planning) dan Manajemen Laba}

Perencanaan pajak digunakan oleh perusahaan dalam upaya meminimalkan pajak yang harus dibayar. Perusahaan dapat berupaya untuk melakukan suatu perencanaan pajak yang sangat baik agar keuntungan pajak bisa diperoleh. Perencanaan pajak yang sangat baik mampu membuat laba bersih perusahaan menjadi berkurang (Wijaya dan Martani, 2011). Ada pengaruh antara manajemen laba dan perencanaan pajak, yaitu semakin tinggi perencanaan pajaknya maka peluang perusahaan melakukan manajemen laba juga semakin besar. Salah satu cara dalam melakukan perencanaan pajak adalah laba yang dilaporkan diatur sehingga akan terindikasi adanya praktek manajemen laba. Oleh karena itu, agar dapat terhindar dari adanya hal-hal tersebut maka suatu perusahaan akan melakukan suatu manajemen laba supaya laba yang dilaporkan kepada fiskal akan lebih kecil sehingga beban pajak yang akan ditanggung oleh perusahaan bisa berkurang.

Wijaya dan Martani (2011) meneliti bahwa perencanaan pajak sangat berpengaruh positif pada praktik manajemen laba. Hal ini dapat diperkuat dengan penelitian yang menunjukkan bahwa perencanaan pajak 
memiliki pengaruh signifikan terhadap manajemen laba, semakin baik perencanaan pajaknya maka semakin besar perusahaan melakukan manajemen laba (Sumomba dan Hutomo, 2012). Dengan demikian, adanya suatu perencanaan pajak dapat berpengaruh pada perusahaan dalam pelaksanaan manajemen laba karena dengan melaksanakan perencanaan pajak maka bisa menurunkan adanya tingkat laba di dalam perusahaan.

\section{H1: Perencanaan Pajak berpengaruh signifikan positif terhadap Manajemen Laba}

\section{Beban Pajak Tangguhan dan Manajemen Laba}

Beban pajak tangguhan merupakan suatu pajak yang pengakuannya dapat ditangguhkan atau ditunda, karena sebagai antisipasi yang dapat dilakukan terhadap konsekuensi utang pajak penghasilan, yang muncul di masa sekarang maupun di masa yang akan dating (Prasetyo, el al, 2019). Semakin tinggi presentase suatu beban pajak tangguhan terhadap total suatu beban pajak perusahaan maka dapat menunjukan standar akuntansi yang semakin liberal. Manajemen laba dapat dikatakan positif di dalam beban pajak tangguhan karena diduga dapat digunakan untuk mengukur suatu pilihan diskresioner manajer karena manajer dapat menggunakan pelaporan pajak yang dapat meningkatkan diskresinya sehingga penghasilan mencapai suatu batas tertentu (Widowati et. al, 2019). Manajer sering diasumsikan cenderung dapat melaporkan laba akuntansi yang lebih tinggi namun tidak pernah melaporkan pajak yang lebih tinggi. Beban yang besar akan membuat laba perusahaan menurun, sehingga perusahaan memiliki peluang untuk memperoleh laba yang lebih besar di masa datang dengan melakukan pengurangan pajak yang akan dibayarkan. Bila motivasi manajemen untuk melakukan suatu manajemen laba semakin besar, maka dapat menyebabkan tingginya perbedaan antara laba akuntansi dan perpajakan. Sehingga beban pajak tangguhan mampu untuk dijadikan suatu indikator di dalam manajemen laba (Sylvia et al, 2016).

Penelitian sebelumnya yang dilakukan Yulianti (2005), Ulfah (2013), Lestari (2018), dan Widowati et al, (2019) membuktikan bahwa beban pajak tangguhan memiliki pengaruh positif signifikan dengan manajemen laba untuk menghindari jika terjadi kerugian yang ada di dalam perusahaan.

\section{H2: Beban pajak tangguhan berpengaruh signifikan positif terhadap manajemen laba}

\section{Kecakapan Manajerial dan Manajemen Laba}

Manajer yang cakap adalah suatu manajer yang memiliki tingkat pendidikan dan kecerdasan yang cukup tinggi serta memiliki pengalaman sehingga mampu untuk membuat suatu keputusan yang tepat, yaitu dapat memberikan nilai tambah bagi suatu perusahaan (Utami dan Syafruddin, 2013). Maka, dengan kecakapan manajerial akan terjadi asimetri suatu informasiyang dapatmendorong manajer dalam pelaksanaan manajemen laba di suatu perusahaan. Berdasarkan hal tersebut, maka dapat disimpulkan bahwa seorang manajer yang semakin cakap, maka intensitas manajemen laba yang dilakukan oleh perusahaan yang akan lebih terampil di dalam mengolah informasi juga semakin tinggi. Terdapat dua hal yang akan menjadi pendorong manajer di dalam melakukan manajemen labanya, yaitu kompensasi bonus dan asimetri informasi antara manajemen dan pemilik perusahaan (Wicaksono dan Yuyetta, 2013).

Hasil penelitan Demerijan (2013) menemukan adanya hubungan positif dan signifikan antara kecakapan 
managerial dengan manajemen laba. Hal ini disebabkan karena seorang manager yang semakin cakap akan mampu menghasilkan laba yang semakin berkualitas dan mereka akan lebih paham dengan adanya risiko yang mungkin akan dihadapi oleh perusahaan. Penelitian tersebut didukung dengan penelitian Saputra (2013), Wicaksono dan Yuyetta (2013), serta Utami dan Syafruddin (2013) yang membuktikan bahwa variabel kecakapan manajerial berpengaruh positif terhadap manajemen laba, manajer yang cakap akan lebih paham dan mengetahui celah untuk melakukan praktik manajemen laba.

\section{H3: Kecakapan Manajerial berpengaruh signifikan positif terhadap Manajemen Laba}

Gambar

Model Penelitian

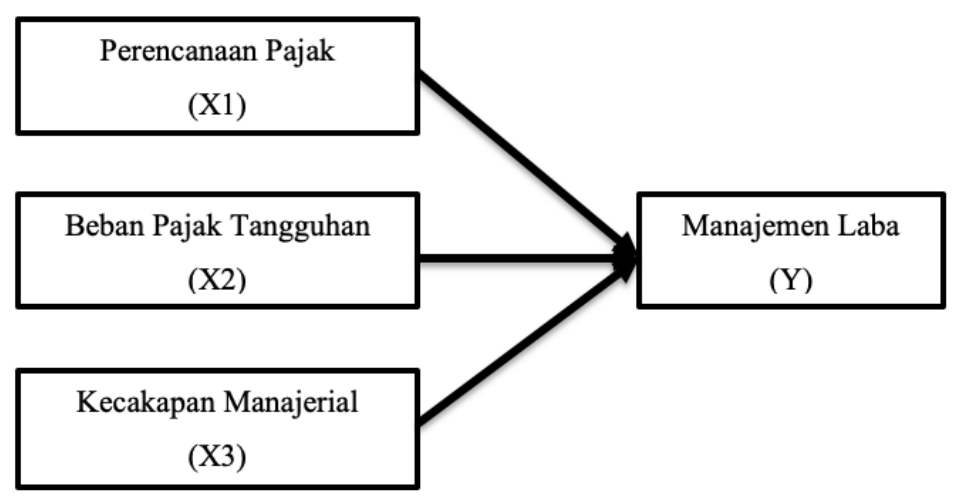

\section{METODE PENELITIAN}

\section{Populasi dan Sampel}

Penelitian ini menggunakan perusahaan manufaktur yang listing di Bursa Efek Indonesia (BEI) dari tahun 2016-2018 sebagai populasi. Sedangkan sampel menggunakan teknik purposive sampling dalam pengambilan sampelnya, yaitu:

1. Perusahaan manufaktur yang mempublikasikan laporan keuangan tahunan secara berturut-turut dalam website BEI selama periode 2016-2018.

2. Perusahaan manufaktur yang menggunakan mata uang rupiah pada tahun 2016-2018.

3. Perusahaan manufaktur di BEl yang mengalami laba secara berturut-turut selama tahun 2016-2018.

\section{Definisi Operasional Variabel}

1. Tax Planning/Perencanaan Pajak

Harnanto (2013) mendefinisikan perencanaan pajak yaitu meminimalisasi penghasilan kena pajak di dalam tahun berjalan yang bisa digambarkan sebagai sebuah maksimalisasi penghasilan kena pajak atau pajak penghasilan yang terhutang dalam tahun berjalan. Pengukuran perencanaan pajak menggunakan Rumus Tax Retention Rate (Wild et al, 2005). 


$$
\mathrm{TRR}_{\mathrm{it}}=\frac{\text { Net Income }_{\text {it }}}{\text { Pretax Income (EBIT) })_{\text {it }}}
$$

TRR $_{\text {it }} \quad$ : Tax Retention Rate perusahaan i pada tahun $\mathrm{t}$

Net Income $_{\text {it }} \quad$ : Laba bersih perusahaan i pada tahun $t$

Pretax Income $(\mathrm{EBIT})_{\text {it }}$ : Laba sebelum pajak i pada tahun $\mathrm{t}$

\section{Beban Pajak Tangguhan}

Menurut Yulianti (2005), beban pajak tangguhan merupakan beban yang muncul karena sebuah perbedaan sementara antara laba akuntansi dan laba fiskal. Adapun rumus dalam variable ini sesuai dengan Philips, et. Al (2003) sebagai berikut:

$$
\mathrm{BBPT}_{\text {it }}=\frac{\text { Beban pajak tangguhan perusahaan i pada tahun } \mathrm{t}}{\text { Total aktiva pada akhir tahun } \mathrm{t}-1}
$$

\section{Kecakapan Manajerial}

Kecakapan manajerial merupakan tingkat keefisienan yang relatif dari perusahaan dalam mengelola faktor sumber daya dan operasional agar output (penjualan) mengalami peningkatan. Factor yang menjadi input dalam perhitungan kecakapan manajerial ada 2, yaitu adanya faktor sumber daya (total aset dan jumlah tenaga kerja) serta faktor operasional (Days Cost of Good Sold in Inventory dan Days Sales Outstanding)

a. Jumlah Tenaga Kerja

Jumlah tenaga kerja adalah faktor suatu sumber daya yang berperan di dalam menghasilkan sebuah penjualan. Dalam menilai penjualan tertentu, jika jumlah tenaga kerja untuk menghasilkan suatu penjualan semakin kecil maka perusahaan semakin efisien.

b. Total Aset

Total aset menjadi salah satu perhitungan input karena aset merupakan sumber daya yang sangat penting di dalam menghasilkan sebuah penjualan (output).

c. Days Cost Of Good Sold in Inventory (DSI)

DSI mengukur jumlah perputaran persediaan perusahaan dalam satuan hari. Jika semakin sedikit waktu (hari) yang digunakan untuk melakukan perputaran persediaan maka perusahaan tersebut semakin efisien. Manajer yang memiliki kecakapan diharapkan dapat mampu mengambil sebuah langkah - langkah yang diperlukan untuk dapat meminimalkan besaran DSI ini.

$$
D S I=\frac{365}{\left(\frac{\text { COGS }}{\text { Inventory }}\right)}
$$


COGS : Jumlah total harga pokok penjualan

Inventory : Persediaan

c. DSO (Days Sales Outstanding)

DSO digunakan untuk mengukur adanya waktu yang dibutuhkan oleh sebuah perusahaan untuk dapat memperoleh kas setelah melakukan penjualan. Perusahaan yang dapat memperoleh sebuah kas kembali, maka semakin cepat ditunjukkannya pengelolaan perusahaan oleh manajer yang cakap. Rumus untuk menghitung DSO adalah:

$$
\text { DSO }=\frac{\text { Receivable }}{\left(\frac{\text { Sales }}{365}\right)}
$$

Receivable : Piutang Usaha

Sales : : Penjualan bersih kredit

Input diatas akan membentuk suatu persamaan, yaitu:

Total Input $=$ Total Aset + Jumlah Tenaga Kerja + DSI +DSO

Sedangkan output dalam perhitungan kecakapan manajerial adalah penjualan. Penjualan digunakan sebagai output karena penjualan menggambarkan nilai nominal dari produk perusahaan yang merupakan output mendasar dari perusahaan. Penjualan tersebut dapat diambil di dalam laporan keuangan yaitu total penjualan.

Sehingga nilai efisiensi tidak melebihi 1 (100\%) dan output serta input yang dilakukan penganalisisan haruslah bersifat positif. Dapat dikatakanjuga, bahwa perusahaan tidakmelakukan suatu pemborosan sumber daya jika bernilai 1 (100\%), sebaliknya jika nilainya $0 \leq<1$, maka suatu perusahaan dapat dinilai inefisien dalam mengelola suatu sumber daya yang ada di dalam perusahaan.

4. Manajemen Laba

Pengukuran yang dilakukan bisa diproksikan dengan menggunakan metode discretionary accrual (DA) yang diukur menggnakan model Jones (1991) modifikasi (Modified Jones model) yaitu:

1. Menghitung total aset dengan rumus:

$$
\mathrm{TAC}=(\mathbf{N I}-\mathrm{CFO} \text { it })
$$

TAC : total akrual i pada tahun $\mathrm{t}$

$\mathrm{NI}$ : laba bersih i pada tahun $\mathrm{t}$

CFO it : kas dari i pada tahun $\mathrm{t}$ 
2. Melakukan pencarian koefisien regresi dengan menggunakan rumus:

$$
\text { TAC } / \text { At }-1=\beta 1(1 / \text { At }-1)+\beta 2(\triangle R E V i t / A t-1)+\beta 3(\text { PPEit } / \text { At }-1)+\varepsilon
$$

At $-1 \quad$ : total aset perusahaan i pada periode $\mathrm{t}-1$ (awal tahun)

$\triangle R E V$ it $\quad$ : pendapatan perusahaan i pada periode t dikurangi pendapatan pada periode $\mathrm{t}-1$

PPEit $\quad$ : aset tetap berwujud kotor perusahaan i pada periode $\mathrm{t}$

3. Melakukan perhitungan Non-discretionary accrual dengan rumus:

$$
\text { NDA = ß1 (1/ At-1) + B2 (DREVit - } \triangle \text { RECit/ At-1) + B3 (PPEit/ At-1) }
$$

$\triangle R E V$ it $\quad$ : pendapatan perusahaan i pada periode t dikurangi pendapatan pada periode t-1

$\triangle R C_{i t} \quad$ : piutang perusahaan i pada periode $t$ dikurangi piutang pada periode $\mathrm{t}-1$

PPEit : aset tetap berwujud kotor perusahaan i pada periode $t$

ß1, ß2, ß3 : koefisien yang diperoleh dari persamaan regresi

4. Melakukan perhitungan discretionary accrual dengan menggunakan rumus:

$$
\mathrm{DA}=(\mathrm{TAC} / \mathrm{At}-1)-\mathrm{NDA}
$$

DA : accrual discretioner perusahaan i pada periode $t$

NDA : non accrual discretioner perusahaan i pada periode $t$

TAC : total akrual perusahaan i pada periode $t$

At -1 : total aset perusahaan i pada periode $\mathrm{t}-1$ (awal tahun)

\section{Teknik Analisis}

\section{Statistik Deskriptif}

Statistik deskriptif merupakan analisis statistik yang dapat menggambarkan/mendeskripsikan data yang dapat diketahui dari nilai mean, maksimum, standar deviasi, sum, range, kurtosis dan skewness. Sehingga statistik deskriptif dapat menggambarkan data menjadi sebuah informasi yang bisa dipahami lebih jelas dan mudah (Ghozali, 2018).

\section{Uji Normalitas}

Uji normalitas digunakan untuk menguji distribusi variabel terikat untuk setiap nilai variabel bebas tertentu yang dapat berdistribusi normal atau tidak (Ghozali, 2018). Uji normalitas bisa dilakukan dengan cara 
melihat besaran yang ada pada Kolmogorov Smirnov.

\section{Uji Multikoleniaritas}

Uji multikoleniaritas adalah suatu situasi dimana ada beberapa atau bahkan semua variabel independen saling berkorelasi tinggi. Uji multikolinieritas menggunakan nilai Variance Inflation Factors (VIF) dan tolerance.

\section{Uji Heteroskedastisitas}

Uji heteroskedastisitas bertujuan untuk menguji model regresi terjadi ketidaksamaan varian dan residual suatu pengamatan yang terjadi ke pengamatan lain dengan menggunakan uji glejser.

\section{Uji Autokorelasi}

Pengujian autokolerasi menggunakan Durbin Watson. Untuk mencari autokorelasi nya dapat dilakukan dengan cara mencocokkan posisi $D W$ dengan $d u, d l, d-d u$, dan 4- $d l$.

a. Apabila $d u<D W<4-d u$ maka terdapat masalah di dalam autokorelasi.

b. Apabila $d u \leq D W \leq d u$ atau 4- $d u \geq D W \geq 4-d l$ maka tidak ada kesimpulan yang dapat diambil.

c. Apabila $D W<d l$ maka terjadi autokorelasi yang bersifat positif.

Analisis Regresi Linier Berganda

Rumus yang dapat digunakna untuk menghitung analisis regresi linier berganda adalah sebagai berikut:

$$
\begin{aligned}
& Y=\alpha+\beta 1 X 1+\beta 2 \times 2+\beta 3 \times 3+\varepsilon \\
& \mathrm{Y} \quad=\text { Manajemen Laba } \\
& a \quad=\text { Koefisien regresi konstanta } \\
& \beta=\text { Koefisien regresi masing-masing proksi } \\
& \mathrm{X}_{1}=\text { Perencanaan Pajak } \\
& \mathrm{X}_{2}=\text { Beban Pajak Tangguhan } \\
& \mathrm{X}_{3}=\text { Kecakapan Manajerial } \\
& \varepsilon=\text { Eror }
\end{aligned}
$$

\section{Koefisien Determinasi}

Koefisien determinasi dilakukan untuk mengukur model tersebut mampu menerangkan variasi variabel independen. Kecilnya nilai $\mathrm{R}$ square mengindikasikan bahwa kemampuan variabel independen di dalam menjelaskan variasi variabel dependen sangatlah terbatas, sebaliknya nilai $R^{2}$ yang mendekati nilai satu mengindikasikan bahwa variabel independen mampu menjelaskan hampir semua informasi yang dibutuhkan dalam mengukur variasi variabel dependen.

\section{Uji Statistik F}

Uji statistik F menunjukkan apakah variable independen secara bersama-sama mampu mempengaruhi variable dependen (Ghozali, 2018).

\section{Uji Parameter Statistik (Uji t)}

Uji t dilakukan untuk mengetahui pengaruh antara satu variabel independen secara parsial di dalam menjelaskan suatu variasi variabel dependen (Ghozali, 2018). Uji statistik t dilakukan untuk menemukan suatu variabel independen yang paling berpengaruh terhadap variabel dependennya. 


\section{HASIL DAN PEMBAHASAN \\ Data Penelitian}

Berdasarkan Tabel dibawah, dapat diperoleh sampel dalam penelitian ini dengan menggunakan syarat tertentu yang sebelumnya telah ditentukan dan dapat diperoleh sampel penelitian yang bisa diolah sebanyak 150 perusahaan manufaktur yang telah go publik di Bursa Efek Indonesia.

Tabel

Penggolongan Perusahaan Manufaktur di Bursa Efek Indonesia

Periode Tahun 2016-2018

\begin{tabular}{|c|l|c|}
\hline No. & \multicolumn{1}{|c|}{ Keterangan } & Total \\
\hline 1 & $\begin{array}{l}\text { Perusahaan manufaktur yang listing dalam BEl pada tahun 2016 hingga } \\
\text { tahun 2018. }\end{array}$ & 173 \\
\hline 2 & $\begin{array}{l}\text { Perusahaan manufaktur yang secara berturut-turut tidak mempublikasi- } \\
\text { kan laporan keuangan tahunan dalam website BEl selama periode 2016 } \\
-2018 .\end{array}$ & $(66)$ \\
\hline 3 & $\begin{array}{l}\text { Perusahaan manufaktur yang tidak menggunakan mata uang rupiah } \\
\text { pada tahun 2016 - 2018. }\end{array}$ & $(23)$ \\
\hline 4 & $\begin{array}{l}\text { Perusahaan manufaktur yang delisting. } \\
\text { tahun 2016-2018 }\end{array}$ & $(11)$ \\
\hline 5 & $\begin{array}{l}\text { Perusahaan manufaktur di BEl yang mengalami kerugian berturut-turut } \\
\text { Jumlah Sampel Penelitian }\end{array}$ & $\mathbf{5 0}$ \\
\hline \multicolumn{2}{|c|}{ Total sampel data untuk penelitian (50 x 3) } \\
\hline
\end{tabular}

\section{Statistik Deskriptif}

Berdasarkan perhitungan statistik, maka data beban pajak tangguhan, kecakapan manajerial, perencanaan pajak, serta manajemen laba pada perusahaan manufaktur di Bursa Efek Indonesia tahun 2016-2018 dijelaskan pada tabel berikut ini:

Tabel

Statistik Deskriptif

\begin{tabular}{|l|r|r|r|r|r|}
\hline & \multicolumn{1}{|c|}{$\mathrm{N}$} & \multicolumn{1}{c|}{ Min } & \multicolumn{1}{c|}{ Max } & \multicolumn{1}{c|}{ Mean } & Std. Deviation \\
\hline Perencanaan Pajak & 150 & .0697 & 11.1714 & .879021 & .9982191 \\
\hline Beban Pajak Tangguhan & 150 & .0000 & .0492 & .011002 & .0111561 \\
\hline Kecakapan Manajerial & 150 & 0 & 8 & 1.17 & .930 \\
\hline Manajemen Laba & 150 & -4.7759 & .3888 & -.568595 & .5934448 \\
\hline Valid N (listwise) & 150 & & & & \\
\hline
\end{tabular}

Dari tabel diatas dapat dijelaskan bahwa statistik deskriptif masing-masing variabel di dalam penelitian pada nilai mean (rata-rata) untuk variabel perencanaan pajak sebesar 0,8790. Hal ini dapat menunjukkan bahwa perencanaan pajak pada perusahaan manufaktur di Bursa Efek Indonesia (BEI) tahun 2016-2018 sebesar 
0,8790; nilai terendah sebesar 0,0697 dan nilai tertinggi sebesar 11,1714 serta standar deviasi sebesar 0,9982 (diatas rata-rata), artinya perencanaan pajak memiliki tingkat variasi data yang tinggi.

Nilai mean (rata-rata) untuk variabel beban pajak tangguhan sebesar 0,0111. Hal ini menunjukkan bahwa beban pajak tangguhan pada perusahaan manufaktur di Bursa Efek Indonesia (BEI) tahun 2016-2018 sebesar 0,0111\%; nilai terendah sebesar 0\% dan nilai tertinggi sebesar 0,0492\% serta standar deviasi sebesar 0,0111 (sama dengan rata-rata), artinya beban pajak tangguhan memiliki tingkat variasi data yang balance atau seimbang.

Nilai mean (rata-rata) untuk variabel kecakapan manajerial sebesar 1,17. Hal ini menunjukkan bahwa kecakapan manajerial pada perusahaan manufaktur di Bursa Efek Indonesia (BEI) tahun 2016-2018 sebesar 1,17\%; nilai terendah sebesar 0\% dan nilai tertinggi sebesar $8 \%$ serta standar deviasi sebesar 0,930 (dibawah rata-rata), artinya kecakapan manajerial memiliki tingkat variasi data yang rendah.

Nilai mean atau rata-rata pada variabel Manajemen Laba yang diukur dengan discretionary accrual diperoleh sebesar -0,5686, yang berarti bahwa manajemen laba yang diterima negatif (mengalami kerugian). Hal ini menunjukkan bahwa perusahaan manufaktur di Bursa Efek Indonesia (BEI) yang dijadikan sampel penelitian dalam penelitian ini memiliki rata-rata Manajemen Laba sebesar -0,5686; nilai terendah sebesar $-4,7759$ dan nilai tertinggi sebesar 0,3888 serta standar deviasi sebesar 0,5935 (diatas rata-rata), artinya manajemen laba memiliki tingkat variasi data yang tinggi.

\section{Uji Normalitas Data}

Table di bawah ini memperlihatkan bahwa distribusi data penelitian memiliki angka probabilitas (Kolmogorov Smirnov) sebesar 0,002 <0,05. Dengan demikian, model regresi dalam penelitian ini berdistribusi tidak normal sehingga belum bisa dilakukan pengujian selanjutnya.

Tabel

Uji Normalitas Data Sebelum Normal

\begin{tabular}{llr} 
& & $\begin{array}{c}\text { Unstandardized } \\
\text { Residual }\end{array}$ \\
\hline $\mathrm{N}$ & Mean & 150 \\
\hline Normal & Std. Deviation &, 0000000 \\
Parameters & 43158954 \\
\hline Most Extreme & Absolute &, 095 \\
\cline { 2 - 3 } Differences & Positive &, 074 \\
\cline { 2 - 3 } & Negative &,- 095 \\
\hline Test Statistic & &, 095 \\
\hline Asymp. Sig. (2-tailed) &, $002^{\circ}$ \\
\hline
\end{tabular}


Tabel

Uji Normalitas setelah Normal

\begin{tabular}{|llr} 
& & $\begin{array}{r}\text { Unstandardized } \\
\text { Residual }\end{array}$ \\
\hline $\mathrm{N}$ & & 147 \\
\hline Normal & Mean & .0000000 \\
\cline { 2 - 3 } Parameters & Std. Deviation & .26607502 \\
\hline Most Extreme & Absolute & .071 \\
\cline { 2 - 3 } Differences & Positive & .071 \\
\cline { 2 - 3 } & Negative & -.052 \\
\hline Test Statistic & & .071 \\
\hline Asymp. Sig. (2-tailed) & $.065^{c}$ \\
\hline
\end{tabular}

Salah satu cara untuk merubah distribusi yang tidak normal agar menjadi normal yaitu dengan cara menghapus data Outliers. Sebanyak 3 data yang dianggap menjadi outliers dihapus. Setelah menghapus data outliers bisa dilihat dimana nilai nya memiliki nilai signifikansi (Kolmogorov Smirnov) sebesar 0,065 >0,05. Dengan demikian, model regresi sudah berdistribusi normal dan bisa dilakukan pengujian selanjutnya.

\section{Uji Multikolinearitas}

Hasil yang diperoleh pada tabel di bawah memperlihatkan bahwa nilai VIF $<10$ dan nilai tolerance $>0,1$. Melihat hasil nilai tolerance dan VIF, dapat mengindikasikan bahwa data-data di dalam penelitian digolongkan bahwa tidak terdapat gangguan multikolinearitas pada model regresinya.

Tabel

Uji Multikolinieritas

\begin{tabular}{|c|c|c|c|}
\hline & \multirow{2}{*}{$\begin{array}{c}\text { Model } \\
\text { Tolerance }\end{array}$} & \multicolumn{2}{|c|}{ Collinearity Statistics } \\
\hline & & \multicolumn{2}{|l|}{ VIF } \\
\hline \multirow{4}{*}{1} & (Constant) & & \\
\hline & Perencanaan Pajak & .931 & 1.074 \\
\hline & Beban Pajak Tangguhan & .905 & 1.106 \\
\hline & Kecakapan Manajerial & .968 & 1.033 \\
\hline
\end{tabular}

\section{Uji Autokorelasi}

Sesuai tabel uji autokorelasi memperlihatkan hasil DW test (Durbin Watson test) $(1,7722<2,021<2,2278)$. Hal ini berarti bahwa di dalam model regresi di bawah tidak terdapat masalah autokolerasi, sehingga model regresi ini dinyatakan layak untuk digunakan. 
Tabel

Uji Autokorelasi (Bebas Autokorelasi)

\begin{tabular}{lccrrr}
\multicolumn{5}{c}{ Model Summary } \\
\hline Model & $\mathrm{R}$ & R Square & Adjusted R Square & $\begin{array}{c}\text { Std. Error of the } \\
\text { Estimate }\end{array}$ & Durbin-Watson \\
\hline 1 & $.215^{\text {a }}$ & .046 & .026 & .23502 & 2.021 \\
\hline $\begin{array}{l}\text { a. Predictors: (Constant), LagX3, LagX1, LagX2 } \\
\text { b. Variabel Dependen: LagY }\end{array}$
\end{tabular}

\section{Uji Heteroskedastisitas}

Berdasarkan hasil uji glejser pada tabel di bawah memperlihatkan nilai signifikansi semua variabel bebas $>0,05$ sehingga menunjukkan data tidak terdapat gangguan heteroskedastisitas. Hasil uji heteroskedastisitas tertera pada output berikut:

Tabel

Hasil Uji Glejser

\begin{tabular}{|c|c|c|c|}
\hline \multicolumn{4}{|c|}{ Coefficients $^{a}$} \\
\hline & Model & $\mathrm{t}$ & Sig. \\
\hline \multirow{4}{*}{1} & (Constant) & 8.951 & .000 \\
\hline & LagX1 & -.651 & .516 \\
\hline & $\operatorname{LagX} 2$ & -.591 & .555 \\
\hline & LagX3 & -1.251 & .213 \\
\hline
\end{tabular}

a. Variabel Dependen: AbsRes3

\section{Uji Koefisien Determinasi $\left(\mathbf{R}^{\mathbf{2}}\right)$}

Pada table di bawah dapat diperoleh nilai $\mathrm{R}^{2}$ model sebesar 0,46 yang berarti adanya pengaruh besar di dalam beban pajak tanggguhan, perencanaan pajak, dan kecakapan manajerial terhadap manajemen laba hanya sebesar $46 \%$ dan sisanya $54 \%$ dijelaskan oleh faktor-faktor lain diluar variabel yang diteliti pada penelitian ini.

Tabel

Koefisien Determinasi

\begin{tabular}{|c|c|c|c|}
\hline \multicolumn{4}{|c|}{ Model Summary } \\
\hline Model & $\mathrm{R}$ & R Square & Adj R Square \\
\hline 1 & $.215^{\mathrm{a}}$ & .46 & .26 \\
\hline
\end{tabular}




\section{Uji Signifikasi Simultan (Uji F)}

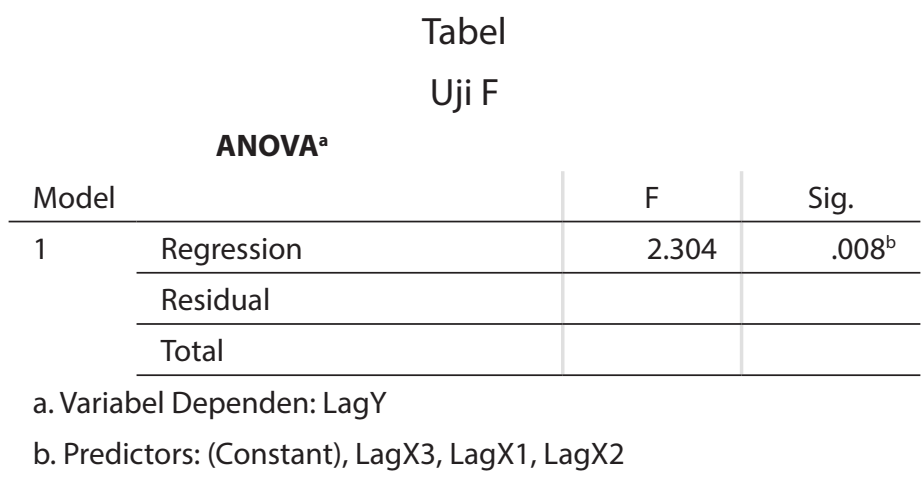

Terlihat pada table diatas, bahwa pada besarnya nilai $\mathrm{F}$ hitung sebesar 2,304 dan nilai signifikansi sebesar $0,008<0,05$. Dengan demikian variabel independen yaitu beban pajak tangguhan, perencanaan pajak, dan kecakapan manajerial secara simultan berpengaruh terhadap manajemen laba.

\section{Uji t (Pengaruh Parsial)}

Tabel

Output Uji t

Coefficients $^{\mathrm{a}}$

\begin{tabular}{|c|c|c|c|c|c|c|}
\hline & \multirow[t]{2}{*}{ Model B } & \multicolumn{2}{|c|}{ Unstandardized Coefficients } & \multirow[t]{2}{*}{$\begin{array}{c}\text { Standardized } \\
\text { Coefficients }\end{array}$} & \multirow[t]{2}{*}{$\mathrm{t}$} & \multirow[t]{2}{*}{ Sig. } \\
\hline & & Std. Error & Beta & & & \\
\hline \multirow{4}{*}{1} & (Constant) & -.297 & .033 & & -8.924 & .000 \\
\hline & LagX1 & .001 & .018 & .003 & .036 & .971 \\
\hline & $\operatorname{LagX2}$ & 5.667 & 2.195 & .215 & 2.582 & .011 \\
\hline & $\operatorname{LagX3}$ & .002 & .042 & .004 & .042 & .966 \\
\hline
\end{tabular}

a. Variabel Dependen: LagY

Model persamaan yang bisa diperoleh dari hasil tabel regresi berganda di atas, sebagai berikut:

$$
Y=-0,297+0,001 \times 1+5,667 \times 2+0,002 \times 3+e
$$

\section{Pengaruh Perencanaan Pajak terhadap Manajemen Laba}

Table Uji T memperlihatkan bahwa nilai Beta untuk variable Perencanaan Pajak sebesar 0,001 dengan nilai signifikansi sebesar 0,971>0,005. Hal ini menunjukkan bahwa perencanaan pajak tidak berpengaruh terhadap manajemen laba. Dengan demikian, hasil penelitian ini menolak Hipotesis 1. Perencanaan pajak merupakan tindakan penstrukturan yang sangat berkaitan dengan konsekuensi potensi pajaknya, yang terjadi pada tiap transaksi yang memiliki konsekuensi pajak (Sumomba dan Hutomo, 2012). Di dalam manajemen laba, perencanaan pajak dapat digunakan sebagai suatu alternatif yang dapat dilakukan oleh suatu manajer di dalam me-manage usaha serta adanya suatu transaksi dari wajib pajak perusahaan supaya utang pajak 
bernilai sangat minimal.

Penelitian ini memberikan hasil bahwa tidak ada pengaruh secara statistik signifikan dan positif antara perencanaan pajak terhadap manajemen laba. Hal ini dapat mengindikasikan bahwa besar kecilnya perencanaan pajak di dalam sebuah perusahaan tidak mempengaruhi manajemen laba.

Perencanaan pajak tidak berpengaruh signifikan karena perencanaan pajak yang semakin rendah mengakibatkan peluang perusahaan melalukan manajemen laba juga semakin kecil. Perencanaan pajak yang dilaksanakan oleh perusahaan mengikuti peraturan perpajakan yang ada dan berlaku, sehingga mereka tidak memiliki cara untuk mengatur seberapa besar laba yang dilaporkan, yang berakibat tidak memiliki indikasi praktik manajemen laba. Selanjutnya, perusahaan manufaktur memiliki berbagai departemen/divisi yang di dalamnya terdapat masing-masing manajemen. Hal tersebut menimbulkan adanya kecenderungan bahwa kepentingan pribadi manajemen akan diprioritaskan dengan tujuan untuk memperoleh reward atas hasil kinerjanya yang telah dicapai. Dengan demikian, manajemen laba bisa saja terjadi karena adanya self interest dari pihak manajemen perusahaan, dan bukan karena adanya perencanaan pajak yang sebelumnya merupakan kepentingan pemilik perusahaan (Wardani dan Santi, 2018). Penelitian ini sesuai dengan hasil yang diperoleh Achyani dan Lestari (2019) yang membuktikan bahwa perencanaan pajak tidak mempengaruhi terjadinya manajemen laba di perusahaan.

\section{Pengaruh Beban Pajak Tangguhan terhadap Manajemen Laba}

Berdasarkan Tabel Uji T, terlihat bahwa nilai Beta untuk variable beban pajak tangguhan sebesar 5,667 dengan nilai signifikansi sebesar 0,011<0,05. Hal ini mengindikasikan terdapat pengaruh positif antara beban pajak tangguhan dengan manajemen laba. Dengan demikian, hasil penelitian ini mendukung Hipotesis 2. Beban pajak tangguhan merupakan suatu pajak yang pengakuannya dapat ditangguhkan atau ditunda, karena sebagai antisipasi yang dapat dilakukan terhadap konsekuensi utang pajak penghasilan, baik yang timbul saat ini maupun waktu yang akan datang. Manajemen laba dapat dikatakan positif di dalam beban pajak tangguhan karena diduga dapat digunakan untuk mengukur suatu pilihan diskresioner manajer karena manajer dapat menggunakan pelaporan pajak yang dapat meningkatkan diskresinya sehingga penghasilan mencapai suatu batas tertentu. Semakin besar dorongan manajemen melaksanakan suatu manajemen laba maka dapat menyebabkan perbedaan antara laba akuntansi dan laba fiskal menjadi semakin besar. Sehingga beban pajak tangguhan mampu menjadi suatu indikator dalam terjadinya manajemen laba. Selanjutnya, hasil ini sesuai dengan penelitian yang sebelumnya telah dilakukan oleh Ulfah (2013), Lestari (2018), dan Widowati et al, (2019) bahwa beban pajak tangguhan berpengaruh positif terhadap manajemen laba.

\section{Pengaruh Kecakapan Manajerial terhadap Manajemen Laba}

Terlihat dari Tabel Uji t bahwa nilai Beta sebesar 0,002 dan nilai signifikansi sebesar 0,966>0,05, yang berarti kecakapan manajerial tidak memiliki pengaruh terhadap tindakan manajemen laba. Selanjutnya, hasil penelitian ini menolak Hipotesis 3. Manajer yang cakap adalah suatu manajer yang memiliki tingkat pendidikan dan kecerdasan yang cukup tinggi serta memiliki pengalaman sehingga mampu untuk membuat 
suatu keputusan yang tepat, yaitu dapat memberikan nilai tambah bagi suatu perusahaan. Maka, dengan kecakapan manajerial akan terjadi asimetri suatu informasi yang mampu memotivasi manajer gaar bersedia melaksanakan manajemen laba di suatu perusahaan. Akan tetapi, penelitian ini memberikan hasil bahwa tidak ada pengaruh antara kecakapan manajerial terhadap manajemen laba.

Seorang manager yang semakin cakap mampu membuat laba perushaan semakin berkualitas dan mereka akan lebih paham dengan adanya risiko yang mungkin akan dihadapi oleh sebuah perusahaan, serta manajer yang cakap merupakan faktor kesuksesan yang dimiliki oleh sebuah perusahaan. Perusahaan yang memiliki manajer yang cakap tidak perlu melakukan manajemen laba agar laba terlihat bagus. Manajer yang mumpuni dan cakap mampu untuk mengambil sebuah laba yang optimal di dalam mengelola sumber daya perusahaan dan untuk mencapai tingkat efisiensi yang tinggi. Manajer dikatakan sebagai pengelola perusahaan dan sekaligus sebagai wakil pemilik perusahaan yang cenderung tidak melakukan suatu praktik manajemen laba, karena manajer berusaha untuk selalu meningkatkan nilai dan kinerja perusahaan sehingga dapat memberikan pelaporan keuangan yang lebih baik bagi para pihak yang berkepentingan (Purwanti dan Rahardjo, 2012).

Hasil penelitian ini sesuai dengan Septiana (2012) bahwa kecakapan manajerial bukan merupakan salah satu factor yang bisa mempengaruhi tindakan manajemen laba. Hal ini dikarenakan seorang manajer yang cakap dan berpendidikan tinggi lebih memilih untuk meningkatkan laba perusahaan dengan meningkatkan penjualan dan kinerja perusahaan, sehingga tidak perlu melakukan manajemen laba yang bisa merusak reputasi perusahaan.

\section{PENUTUP}

\section{Kesimpulan}

Sesuai dengan hasil pada penelitian ini, maka bisa ditarik beberapa kesimpulan yaitu perencanaan pajak dan kecakapan yang dimiliki manajer tidak memiliki pengaruh yang signifikan pada manajemen laba. Sedangkan, beban pajak tangguhan memiliki pengaruh positif pada manajemen laba. Adanya pengaruh yang signifikan dan positif ini dapat mengindikasikan bahwa semakin tinggi beban pajak tangguhan sehingga mengakibatkan peningkatan manajemen laba.

\section{Keterbatasan Penelitian}

Penelitian ini memiliki beberapa keterbatasan yaitu, periode pengamatan yang kurang luas, sehingga hasil penelitian belum terlalu menggeneralisasi terjadinya manajemen laba. Selain itu, nilai $R$ square hanya sebesar 46\%, yang mengindikasikan masih banyak variabel lain yang tidak digunakan dalam penelitian yang dapat mempunyai pengaruh terhadap manajemen laba.

\section{Saran}

Saran yang bisa diambil dari penelitian ini adalah menambah variabel yang mampu mempengaruhi perusahaan di dalam manajemen laba, seperti variabel ukuran perusahaan, profitabilitas, leverage, kepemilikan 
manajerial dan sebagainya. Selain itu, dapat menambah sampel perusahaan sektor lain atau menggunakan seluruh sektor perusahaan dan diharapkan dapat memperluas serta menambah sampel perusahaan yang dapat digunakan di dalam penelitian agar lebih efisien dan diduga dapat berpengaruh kuat terhadap manajemen laba, misalnya perusahaan sektor nonmanufaktur.

\section{DAFTAR PUSTAKA}

Achyani, Fatchan dan Lestari, Suci. 2019. Pengaruh Perencanaan Pajak Terhadap Manajemen Laba. Jurnal Riset Akuntansi dan Keuangan Indonesia. Vol. 4 No. 1.

Aditama, Ferry, dan Anna Purwaningsih. 2014. Pengaruh Perencanaan Pajak Terhadap Manajemen Laba Pada Perusahaan Nonmanufaktur yang Terdaftar di BEI. MODUS. Vol. 26 No. 1.

Demerjian, P. R., Lev, B., Lewis, M. F., \& McVay, S. E.2013. Managerial Ability and Earnings Quality. The Accounting Review, 88(2), 463-498.

Djamaludin, dkk. 2008. Analisis Pengaruh Perbedaan Antara Laba Akuntansi Dan Laba Fiskal Terhadap Persistensi Laba, Akrual, Dan Arus Kas Pada Perusahaan Perbankan Yang Terdaftar Di Bursa Efek Jakarta. Jurnal Riset Akuntansi Indonesia. Vol. 11.

Ettredge, et al. 2008. Is Earning Froud Associated With High Deferred Tax and/or Book Minus Tax Levels. $A$ Journal Of Practice And Theory. Vol 27, No 1, Pp 1-33

Ghozali, Imam. 2018. Aplikasi Analisis Multivariete Dengan Program IBM SPSS 23. Cetakan ke VIII. Semarang : Badan Penerbit Universitas Diponegoro.

Healy, P., dan Wahlen J. 1999. A Review of The Earnings Manajement Literature and Its Implications for Standard Setting. Accounting Horizon. 12(4).

Jones, Jennifer J, 1991. Earnings Management During Import Relief Investigations. Journal Of Accounting Research, Vol 29, No.2 1991, p.193 - 228.

Lestari, Fibria Anggraini Puji. 2018. Pengaruh Profitabilitas dan Beban Pajak Tangguhan Terhadap Manajemen Laba. Jurnal Sosio E-kons. Vol. 10 No. 3.

Philips, John et al. 2003. Earnings Management: NewEvidence Based on Deferred Tax Expense. The Accounting Review, Vol. 78.

Prasetyo, Novi Catur, Riana, dan Endang Masitoh. 2019. Pengaruh Perencanaan Pajak, Beban Pajak Tanggugan, dan Kualitas Audit Terhadap Manajemen Laba. MODUS. Vol. 31 No. 2.

Purwanti, Rahayu Budi dan Rahardjo, Shiddiq Nur. 2012. Pengaruh Kecakapan Manajerial, Kualitas Auditor, Komite Audit, Firm Size, dan Leverage Terhadap Earnings Management. Undergraduate Thesis. FEB Universitas Diponegoro.

Puspita, E., \& Kusumaningtyas, D. 2017. Pengaruh Mekanisme Kepemilikan Manajerial, Kecakapan Manajerial, Tingkat Pengungkapan Laporan Keuangan Terhadap Manajemen Laba Dengan Kualitas Audit Sebagai Variabel Intervening, Jurnal Ilmiah. 31-35. Retrieved from http://ojs.unpkediri.ac.id 
Romatis, Oma, Kurnia Heriansyah, Soemarsono DW, Widyaningsih Azizah. 2020. Pengaruh Perencanaan Pajak

Terhadap Manajemen Laba Yang Dimoderasi Oleh Penurunan Tarif Pajak (Diskon Pajak). Jurnal IImiah Akuntansi dan Manajemen. Vol. 16 No. 1.

Saputra,David. 2013. Pengaruh Kecakapan Manajerial Terhadap Manajemen Laba Dengan Komposisi

Dewan Komisaris Sebagai Variabel Pemoderasi. Jurnal Ilmiah, Universitas Lampung.

Septiana, Heryn. 2012. Pengaruh Kecakapan Manajerial dan Kepemilikan Manajerial Terhadap Praktik Manajemen Laba. Jurnal IImiah Mahasiswa FEB. Universitas Brawijaya. Vol. 2 No. 1.

Sulistyanto, H. Sri. 2008. Manajemen Laba, Teori dan Model Empiris. Jakarta: Grasindo.

Sumomba, Christina Ranty dan Hutomo, YB. Sigit. 2012. Pengaruh Beban Pajak Tangguhan dan Perencanaan Pajak Terhadap Manajemen Laba. Jurnal Kinerja. Vol 16, No.2, Hal 103-115.

Sylvia, Puspahadi Boenjamin, dan Susi Dwi Mulyani. 2016. Pengaruh Beban Pajak Tangguhan, Perencanaan Pajak dan Debt to Equity Ratio Tehadap Praktik Manajemen Laba. Jurnal Informasi, Perpajakan, Akuntansi dan Keuangan Publik. Vol. 11 No. 2.

Ulfah, Yana. 2013. Pengaruh Beban Pajak Tangguhan dan Perencanaan Pajak Terhadap Praktik Manajemen Laba. Prosiding Simposium Nasional Perpajakan 4.

Utami, Radityas dan Syafruddin, Muchammad. 2013. Pengaruh Kecakapan Manajerial Terhadap Manajemen Laba Dengan Kualitas Auditor Sebagai Variabel Pemoderasi. Diponegoro Journal of Accounting. Vol. 2 No. 2.

Wardani, Dewi Kusuma dan Desifa Kurnia Santi. 2018. Pengaruh Tax Planning, Ukuran Perusahaan, Corporate Social Responsibility (CSR) Terhadap Manajemen Laba. Jurnal Akuntansi, 6(1): 11-24.

Wicaksono, Annas Budi dan Yuyetta, Etna Nur Afri. 2013. Pengaruh Kecakapan Manajerial Terhadap Praktik Manajemen Laba Dengan Corporate Governance Sebagai Variabel Moderasi. Diponegoro Journal of Accounting. Vol. 2 No. 4.

Widowati, Rani Ayu, M. Agus Sudrajat, dan Nik Amah. 2019. Pengaruh Beban Pajak Tangguhan Terhadap Manajemen Laba Dengan Komite Audit Sebagai Pemoderasi (Pada Perusahaan Manufaktur Subsektor Otomotif yang Terdaftar di BEI). Seminar Inovasi Manajemen, Bisnis, dan Akuntansi I.

Wijaya, Maxson dan Dwi Martani. 2011. Praktik Manajemen Laba Perusahaan Dalam Menanggapi Penurunan Tarif Pajak Sesuai UU No. 36 Tahun 2008. Simposium Nasional Akuntansi XIVAceh.

Wild, John J.et al 2005. Analisis laporan keuangan. Edisi 8. Jakarta: Salemba Empat.

Wiryandari, Santi Aryn dan Yulianti, 2009. Hubungan Perbedaan Laba Akuntansi \& Laba Pajak Dengan Perilaku Manajemen Laba Dan Persistensi Laba. Simposium Nasional Akuntansi XII, Palembang.

Yulianti. 2005. Kemampuan Beban Pajak Tangguhan Mendeteksi Manajemen Laba. Jurnal Akuntansi dan Keuangan Indonesia. 